\title{
ZAPISOVANIE NÁREČOVÝCH TEXTOV V KNIŽNÝCH VYDANIACH VO VOJVODINE*
}

Predmetom nášho výskumu je kniha Kataríny Mosnákovej-Bagl’ašovej Enike benike krikel bé. Autorka svoju knihu nazvala l'udová slovesnost' pre deti Slovákov v Srbsku.

Autorka Mosnáková-Bagl’ašová pri zapisovaní nárečových textov (vyčítaniek, riekaniek, básničiek a pesničiek) nepostupovala dôsledne vo všetkých textoch. Niektoré texty sú zapísané spisovnou slovenčinou, iné zase nárečím a pri niektorých ide o zmiešanie dvoch podôb. V úvode, predslove sa žiada vysvetlenie ako sa bude zapisovat' nárečový materiál. Takú kapitolu sme v knihe nenašli. Preto sa $\mathrm{v}$ práci pokúsime porovnat' s podobnými knihami, $\mathrm{v}$ ktorých je zapísaný nárečový materiál a porovnáme na aký spôsob iní autori zapisovali. Ak texty tohto typu zapíšeme spisovnou slovenčinou, stráca sa prvotný zámer a ciel' autora.

Klúčové slová: nárečové slovo, transkripcia, spisovná slovenčina.

The subject of our research will be a monograph by Katarína Mosnáková-Bagl'ašová Enike benike krikel be. The author called this memoir folk literature for Slovak children in Serbia.

Author Mosnáková-Bagl’ašová did not proceed consistently in all texts when writing dialectal texts (readings, rhymes, poems, and songs). Some texts are written in Standard Slovak, others in dialects, and some are mixed in both forms. In the introduction, the foreword announces an explanation of how to write the dialectal material. We have not found such a chapter in the book. Therefore, we will try to compare it with similar monographs in which the dialectal material is recorded and compare how other authors wrote. If texts of this type are written in Standard Slovak, the original intention and aim of the author is lost.

Keywords: dialectal word, transcription, Standard Slovak.

Predmetom nášho výskumu je zbierka textov z l’udovej slovesnosti Kataríny Mosnákovej-Bagl'ašovej Enike benike krikel bé, ktorá vyšla roku 2017 v Slovenskom vydavatel'skom centre z Báčskeho Petrovca a v Ústave pre kultúru vojvodinských Slovákov v Novom Sade v edícii Včielka. Kniha obsahuje 103 strán a ilustrácie mal na starosti Miroslav Cipár. Ako podnázov knihy sa uvádza Ludová slovesnost’ pre deti Slovákov v Srbsku. To, čo nás zaujalo, sú texty veršov, vyčítaniek, veršovaniek, riekaniek, vinšov, pesničiek, vlastne ako sú tie texty zapísané. Ako autor Doslovu L’ubomír Feldek uvádza, Bagl'ašová štúdiá absolvovala na Oddelení slovakistiky Filozofickej fakulty v Novom Sade. Väčšina textov, ktoré sú v spomenutej knihe, spracované boli aj v master práci Detskýfolklór Slovákov v Jánošíku. Autorka týchto riadkov bola členkou komisie pri obhajobe master práce. Preto nás prekvapuje, že v uverejnenej podobe nastali až také modifikácie textu. Možno to bol zásah ja-

* Tento príspevok je parciálnym výsledkom v rámci republikového projektu Diskurzy menšinových jazykov, literatúr a kultúr v juhovýchodnej a strednej Európe (178017), ktorý financuje Ministerstvo osvety, vedy a technologického rozvoja Republiky Srbsko. 
zykovej redaktorky? Prekvapuje nás aj to, že ani jednou vetou sa nespomína, že je to čast' master práce.

Kniha Kataríny Mosnákovej-Bagl'ašovej Detstvo našich predkov, ktorá vyšla o rok skôr (2016) ako kniha Enike benike krikel bé. Je to vlastne pôvodná master práca. Ked' ide o zapisovanie nárečových slov môžeme konštatovat', že sa dôsledne uplatňuje čitatel'ská transkripcia pri zapisovaní nárečových textov. Pri inej príležitosti sa venujeme rozboru textov v knihe Detstvo našich predkov. Teraz svoj výskum zameriame na knihu Enike benike krikel bé.

Na piatej strane autorka sa obracia čitatel'ovi, že má íst' von, na ulicu, na dvor, na ihrisko hrat' sa... ,Ak náhodou nebudeš vediet', ako sa tam zabavit', ponúkame Ti túto veselú a pestrofarebnú knižku, plnú starodávnych hier a rozprávok, ktoré síce trošku zapadli prachom, ale predsa ani dodnes nestratili svoj pôvab.“ (MosnákováBagl'ašová 2017) V knihe sa striedajú piesne, rozličné vyčítanky, riekanky, veršovanky, rečňovanky, vinše a hry. Autorka v texte vysvetl'uje ako sa uvedená hra hrá. Text je vytlačený čiernou farbou. Potom nasleduje text piesne, riekanky, vinša, rečňovanky, ktorý je vytlačený červenou farbou. Nás zaujal text vytlačený červenou farbou. Vo väčšine sú to texty, ktoré majú nárečovú podobu (ide o stredoslovenské nárečie z Jánošíka, Aradáča a Kovačice). Na šiestej strane je zapísaný text piesne, ktorú deti spievajú pri hre takto:

My sme deti veselé,

radi sa mi zaihráme,

radi si mi zaspievame,

ale teraz nič neznáme.

Po prečítaní uvedených veršov dostali sme sa do pomykova, či sú verše zapísané v spisovnej slovenčine alebo nárečím. Žial', musíme konštatovat', že na položenú otázku ako lingvistka nemôžeme dat' odpoved'. Je to nejaká zmiešanina, spisovného jazyka a čiastočne nárečia. Ale nie sú dodržané a uplatnené ani pravidlá nárečovej transkripcie. $\mathrm{V}$ druhom a tret’om verši príslovka radi je napísaná s mäkkým $i$ a osobné zámeno pre prvú osobu množného čísla v prvom verši v spisovnom jazyku a v druhom a tret'om verši podl'a uvedeného zápisu ide o osobné zámeno pre prvú osobu $\mathrm{v}$ datíve kratší tvar (ak je text zapísaný spisovnou slovenčinou).

Ďalšia pieseň na siedmej strane je zapísaná takto:

Ja mám v l'avej nohi trna, trna, trnavičku

ja mám v l'avej nohi trna, trna, trn.

De máš trn, de máš trn?

Chodila som po hájičku,

trhala som trnavičku,

ja mám v l'avej nohi trna, trna, trnavičku

ja mám v l'avej nohi trna, trna, trn.

V uvedenej piesni sú nárečové slová a tvary: nohi, de, trn. Pod uvedenými veršami sa uvádzajú noty s textom piesne. Tu je už iný zápis: uvedené nárečové slová zostávajú, ale aj: d’e, chod'ila ide o uplatnenú nárečovú transkripciu (takto sa uvádza aj v master práci). Malý čitatel' a možno aj rodičia, po prečítaní uvedených veršov, si môžu položit’ otázku prečo je tu teraz mäkčeň. Rovnako je zapísaný text v notovej 
časti piesne na s. 24 Gúl'alo sa, gúlalo, červenvo jabíčko, ňehňevaj sa, má milá, mé milé srdečko. Po notovej časti uvádza sa text piesne bez vyznačenia mäkkosti v slove nehnevaj. Na 26. strane pod notami vo veršoch piesne vyznačená je mäkkost' spoluhlások l', n̆:

Zel'ení je petržl'aňík, červená je mrkvička.

Mám frajera visokiho a ja som maličká.

Kým v texte piesne bez nôt uvedená mäkkost' nie je vyznačená. Aj d'alej v knihe v notovej časti vo všetkých slovách dôsledne sa vyznačuje mäkkost' spoluhlások d', t', l', ň: s. 29 (žeňilo), s. 45 (d'jet'a, doňesjem, t'i, mil'í), s. 46 ( usňi), s. 46 (bud'e, t’ebou, spat'i, bud'em, kol'embat'i), s. 59 (pšeňičku, vivolili'i, prepel'ičku, ňemá, pod't'e, d'etii), s. 71 (ňeškavdá, d'e, kostol'e), s. 73 (linder), s. 79 (id'e, ulici, ňim, dohoňím, príd'eš, ti), s. 86 (prepl'etá), s. 91 (gazd'iná, ňedáš). V časti, ked' sú verše pesničiek zapísané bez nôt, uvedená mäkkost' spoluhlások nie je vyznačená.

Pri zapisovaní nárečových textov uplatňuje sa tzv. transkripcia. V Slovniku slovenských náreči I $A-K$ (1994) na s. 41 sa uvádzajú pravidlá nárečovej transkripcie, ako sa $\mathrm{v}$ dialektologických textoch zapisujú jednotlivé grafémy. V slovníku sú jednotlivé heslá zapísané podl'a tzv. verejnej čitatel'skej transkripcie. Podla uvedených pokynov mäkké spoluhlásky d', t', l', ň sa označujú dôsledne. Podl'a uvedeného slová d'e, chod'ila v piesni zo siedmej strany sú zapísané podl'a pravidiel nárečovej transkripcie. Teda, ak autorka mala $\mathrm{v}$ úmysle uplatnit' nárečovú transkripciu, mienime, že mala dôsledne postupovat' pri uplatňovaní nárečovej transkripcie. V roku 2010 profesorka Anna Marićová uverejnila monografiu Slovenská nárečová lexika Starej Pazovy (Marićová 2010). Uvedieme niekol'ko príkladov ako autorka zapísala vo svojom slovníku mäkkost' spoluhlások d', t', l', ň: obd'al'ečňi (Marićová 2010: 118), plátenko (Marićová 2010: 137), siliti' (Marićová 2010: 164), taňečňík (Marićová 2010: 190). Dialektológiou vo vojvodinskom prostredí sa zaoberal univerzitný profesor Daniel Dudok. Uverejnil viacero monografií, ale uvedieme dve a z nich aj ukážky, ako zapísal nárečový materiál: Čítanka nárečových textov Slovákov v Báčke, Banáte, Srieme a Slavónsku (Dudok 2010) a Nárečie Aradáča v Banáte na pozadí vzniku a vývinu obce (Dudok 2013). Okrem iného dialektológ profesor Daniel Dudok uvádza v uvedených monografiách aj ukážkové nárečové texty a „nárečový materiál zaznačuje spôsobom, aký sa uplatňuje v slovenskej dialektológii.“ (Dudok 2013: 14) Autor uvádza, že graficky sa označuje mäkkost' každej spoluhlásky, ked' sa tak vysloví: d’ed’ina, d'iňa, (Dudok 2013: 84), kl'epotat', jel'em, jasl'e (Dudok 2013: 87), uhlia, ulic, vet'erňík (Dudok 2013: 96). Nárečové texty sú zapísané aj v Praktickej dialektológii (Múcsková - Muziková - Wambach 2012). Aj v uvedenej vysokoškolskej príručke sa dôsledne zapisuje mäkkost' spoluhlások d', t', l', ň. Uvedieme niekol'ko ukážok zo stredoslovenského nárečia ňemohl'i, ňigd'e, prasl'icu, d’ioučence, smet'i, ňekcela, sl'epie (Múcsková et al. 2012: 91). Mienime, že autorka Mosnáková-Bagl'ašová pri zapisovaní piesní mala postupovat' dôsledne, bud'to vyznačovat' mäkkost' spoluhlások alebo nie. Alebo jednoducho napísat' v úvode knihy ako sa bude postupovat' pri zapisovaní nárečového textu.

Pri vernej čitatel'skej transkripcii pri zapisovaní samohlások krátkych a dlhých v stredoslovenskom nárečí sa nezapisujú grafémy y, ý, ä (Slovník slovenských nárečí I 1994: 41, Marićová 2010: 15). V spomínanej knihe na s. 10 text rečňovanky, ktorý sa rieka pri hre, je zapísaný takto: 


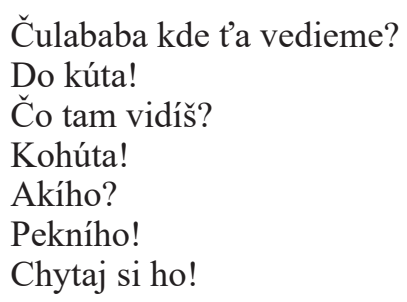

Uvedený text rečňovanky zarad’ujeme do nárečových textov podl'a opytovacieho zámena akího a prídavného mena pekního. Podla Slovníka slovenského nárečia I (Slovník slovenských nárečí I 1994: 759) opytovacie zámeno kde v stredoslovenskom nárečí má tvar de. Rovnako tak aj sloveso chytaj podl'a čitatel'skej nárečovej transkripcie zapíšeme chitaj.

Podl'a uvedeného pravidla o zapisovaní samohlások v nárečových textoch navrhujeme zapísat' aj uvedený text na strane 14:

Deti: Jastrab, jastrab, čo kceš?

Jastrab: Mäso.

Deti: My ti ho nedáme.

Jastrab: Ja si ho zoberiem!

Tzv. široké ä pri nárečovej transkripcii sa nezapisuje, ale obyčajné e a rovnako tak aj zámeno pre prvú osobu množného čísla my s mäkkým i. Na nárečový text odkazuje sloveso kceš. Pri zapisovaní samohlásky široké ä autorka nepostupovala dôsledne. V predchádzajúcom príklade sme uviedli zápis podstatného mena s ä (mäso) a na s. 50 s obyčajným e:

Jeden, dva, tri, štyri, pet',

čo dáš, mamko, čo dáš jest?

Zemiaky pečené,

len sú málo mastené.

Autorka uvádza, že ide o vinš, ktorý si zavinšujeme pred jedlom. Z lingvistického hl'adiska okrem pet' a mamko všetky uvedené slová sú zapísané v spisovnej slovenčine. Tvar mamko sa uvádza v Slovníku súčasného slovenského jazyka (Slovník súčasného slovenského jazyka 2015: 71) ako zastaraný výraz. V slovníku okrem iných príkladov uvádza sa aj príklad z l'udovej piesne. Ak by sa spisovné podoby pretransformovali do nárečia, rým by sa neporušil. Teda dôsledne dodržiavat' bud' spisovnú podobu, alebo nárečovú podobu. Presne vieme, že v stredoslovenskom nárečí nemáme tvar jeden ale edom, nie zemiaky ale krumpl'e, prídavné mená ženského rodu v nominatíve množného čísla majú zakončenie na -ie: pečeňie, mast'eňie. Obyčajné e (svetimu, svetí) je zapísané aj v piesni na s. 96:

Kiselica kiselá, kde si kl'úče podela,

hl'adala som, hl'adala,

ta dala som, ta dala,

svetimu Ďurovi.

Svetí Ďuro vstávaj,

kl'úče odberávaj. 
Na nárečovú podobu odkazuje tvar datívu jednotného čísla mužského prídavného mena na -imu. Na transkribovanú podobu odkazujú lexémy kiselica, svetí. Žiada sa úprava zámena kde do nárečovej podoby stredoslovenského nárečia d’e a sloveso vstávaj $\rightarrow$ stávaj. Obyčajné e je zapísané aj na strane 42: Pred potokom, za potokom pet' kôp konopí. Na s. 65 sa vyskytla samohláska široké ä, ale v tomto kontexte ide o spisovnú podobu jazyka, autorka píše Naučme sa naspamät'.. Uvádzame niekol'ko príkladov zápisu samohlásky ä u Marićovej: mesoví (Marićová 2010: 103), peta, petore (Marićová 2010: 134). Ked' ide o zapisovanie tvrdého a mäkkého y/i strieda sa to v knihe aj tak, aj tak, od začiatku do konca.

Prídavné mená v stredoslovenskom nárečí podl'a Múcskovej (Múcsková et al. 2012: 91) v genitíve a datíve jednotného čísla mužských podstatných mien (a v A, jednotného čísla životných podstatných mien) a podstatných mien stredného rodu majú koncovky -iho, -imu (dobriho, dobrimu, cudziho, cudzimu) teda, tvrdého a mäkkého vzoru. Uvedená konštatácia je zaznamenaná aj v analyzovanej knihe autorky Kataríny Mosnákovej-Bagl'ašovej aj v predchádzajúcej ukážke (svetimu, stariho s. 96) a v d’alších: pekního (s. 10), noviho (s. 12), vysokiho (s. 25). Nominatív a akuzatív množného čísla mužských, ženských a stredných prídavných mien so zakončením na -ie: zlatie, štrbatie (s. 14), malie (s. 19). Nominatív jednotného čísla prídavných mien stredného rodu so zakončením na -uo: drobnuo, miluo (s. 45), na s. 25 máme zápis so -vo: červenvo. $V$ d’alších textoch rečňovaniek, pesničiek, veršovaniek tvary prídavných mien sú zapísané v spisovnej podobe, napr.: veselé (s. 6), čistý (s. 19), milé (s. 25), špatné (s. 34) a pod.

Vo vinši na 77. strane je zapísané takto:

Ja viem, čo vy tu čakáte,

že vy prázdne hurky máte,

polievku si zachlípajte,

ved' je dobrá, rezancová,

korením je posypaná,

kuchárke ju uvarili,

aby ste ju vi užili.

Pán starejší, prímte vd’ačne!

Do nárečového textu uvedený vinš zarad’uje tvar podstatného mena ženského rodu v nominatíve množného čísla kuchárke, sloveso prímte a hovorové slovo hurka. Ked' ide o zapisovanie y a i tu máme v prvom a v druhom riadku pri osobnom zámene pre druhú osobu množného čísla spisovný zápis s ypsilonom a v predposlednom riadku s mäkkým i. Ak by sme uvedený vinš transformovali do nárečovej podoby vyznelo by to takto: prázdne $\rightarrow$ prázňe, hurky $\rightarrow$ hurke, polievku $\rightarrow$ pol'iouku, ved’ $\rightarrow$ ve, vd’ačne $\rightarrow$ d’ačňe.

Dvojhlásky ia, ie, iu pri čitatel'skej nárečovej transkripcii sa zapisujú ako v spisovnom jazyku a nie ako je: čjerno (s. 71), takje (s. 86). Dvojhláska ô sa zapisuje ako uo a nie ako vo nvoškami, nvoške (s. 86). Uvedený zápis sa vyskytol ako zápis pod notami, kým na nasledovnej strane (s. 87) zapísané sú verše s dvojhláskou ô ako v spisovnom jazyku:

Tam hore, tam dolu beží zajac, prepletá nôžkami ako najviac.

Aj ja by tak prepletala, 
keby takie nôžke mala,

ako zajac, ako zajac.

Na nárečovú formu poukazujú tvary ukazovacieho zámena takie a množné číslo podstatného mena ženského rodu nôžke (ked’že sa základ končí na spoluhlásku -k). Aby pieseň bola zapísaná v nárečovej podobe, bolo potrebné zapísat' takto: nôžkami $\rightarrow-$ nuožkami, by $\rightarrow$ bi, keby $\rightarrow$ kebi, nôžke $\rightarrow$ nuožke. V niektorých textoch autorka zapísala dvojhlásku ô: pomôže, pomôž (Mosnáková-Bagl'ašová 2017: 30), kôp (tamže 42), pôjda (tamže 49), vôkol (tamže 50), vrkôčky (tamže 52). Uvedieme niekol'ko príkladov ako dvojhlásku ô zapísala profesorka Marićová: nuoška, nuota (Marićová 2010: 116), buob, buobovíňa (Marićová 2010: 32), kuom, kuorka (Marićová 2010: 92). V niektorých pozíciách, tam kde sa v spisovnom jazyku vyskytuje dvojhláska ô, môžeme mat' v stredoslovenskom nárečí dlhé ó: stóu (Marićová 2010: 172). Dvojhláska ô je zapísaná aj v texte na 35. strane:

Slimák brnák, vystrč rožke

na parôžke,

ak nevystrčíš, puknem t’a o zem,

bude $\mathrm{z}$ teba kázeň.

Slimák Janko vindi von,

ak nevindeš von, podpálim ti dom,

a ty zhoríš $v$ n̆om.

To, čo nám v prvej chvíli upútalo pozornost', bol zápis dvojhlásky ô v slove parôžke. Ďalšie, čo sme si všimli, je tvrdé y pri vystrč, nevystrčíš, ty a potom s mäkkým vindi, nevindeš. Nárečové podoby slov rožke, parôžke, vindi, nevindeš, brnák. V uvedenej piesni ide o striedanie textu zapísaného v spisovnej podobe a v nárečovej. Nárečová transkripcia sa dala uplatnit’ v slovách vistrč, paruožke, nevistrčíš, kázem, ti. Neživotné podstatné mená mužského rodu a podstatné mená ženského rodu, ktorým základ sa končí na spoluhlásky k, h, ch v nominatíve a akuzatíve množného čísla v stredoslovenskom nárečí majú zakončenie na -e. V uvedenej vyčítanke sa vyskytli príklady spomenutej charakteristiky: rožke, parôžke a sú aj d’alšie príklady hrnčoke (s. 19), gazdinke (s. 19), stoučoke s. (64), kuchárke (s. 77).

Pravdepodobne aj riekanka na stranách 16. a 17. je upravená nárečová podoba do spisovného jazyka, lebo sa vyskytla podoba príd'e (vyznačená mäkkost' spoluhlásky pred e) $a$ kušniar.

Ťap, t’ap, t’apušky, išli mačky na hrušky

podriapali kožušky, povešali na vráta, popadali do blata, príd'e kušniar popláta.
Ťap, t’ap, t’apuške, išl'i mačke na hruške podriapal'i kožuške, povešal'i na vráta, popadal'i do blata, príd'e kušňiar popláta.

Ked’že sa v úvode a doslove uvádza, že ide o starodávne hry z Jánošíka, Aradáča a Kovačice určite budú tvary: t’apuške, hruške kožuške. Z l'avej strany sme uviedli text z knihy Enike benike krikel bé a vedl'a neho text transformovaný do čitatel'skej nárečovej transkripcie. 
Na nárečovú podobu veršov pripomína aj tvar podstatného mená mlinčoku, máčok, koláčok na strane 17. Aj podstatné meno mlinčok je napísané s mäkkým i. Ostatné tvary vo veršoch majú spisovnú podobu:

Cicúšky - macúšky kde ste boli?

V mlinčoku.

A čo ste robili?

Koláčiky piekli.

Prišiel máčok, zjedol koláčok,

šic, duko, šic, šic, šic!
Cicúške - macúške d'e st'e boli?

V mlinčoku.

A čo st'e robili??

Koláčike piekl’i.

Prišou máčok, zedou koláčok, šic, duko, šic, šic, šic!

Odporúčame aj ostatné tvary upravit' do nárečovej podoby aby sme nemali zmiešaninu spisovného jazyka a nárečia. Z l'avej strany sme uviedli podobu veršov z knihy a z pravej strany transkribovanú podobu veršov.

V hre na strane 19. pomenovanej hra na hrnčoke (už samotný názov je v nárečí) prvé dva riadky v rečňovanke sú zapísané v nárečí: Kupujem, kupujem hrnčoke stále, gazdinke predajte, čo akie malie. V d’alších dvoch veršoch sa strieda nárečová a spisovná podoba jazyka:

Veliký i malučký, deravý, čistý,

ak ja driou dobehnem, bude moj istý.

Pod rečňovankou je text, v ktorom autorka vysvetl'uje ako sa uvedená hra hrá. Dva razy sa vyskytla nárečová podoba hrnčoke hrnčok, ktoré sú zapísané iným typom písma, italikom, a dva razy spisovná podoba hrnček a k hrnčeku. Odporúčame byt' dôsledný pri používaní tvarov, lebo malý čitatel' sa dostane do pomykova. Názov vyčítanky na 24. strane Ide kacúr je v nárečovej podobe, žiada sa úprava spisovnej podoby slov: pieseň, jeden do nárečovej podoby: pesem, edom a pri osobnom zámene namiesto ty $\rightarrow$ ti: Id’e kacúr po rebríku, natahuje harmoniku. Akú pesem hrá, kto $\mathrm{z}$ vás ju pozná? Edom dva, tri, povedz mi to ti!

L-ové príčastie $\mathrm{v}$ tvaroch minulého času mužského rodu v stredoslovenskom nárečí má zakončenie na -u oproti spisovnej podoby na -l. Pri zapisovaní podla verejnej čitatel'skej transkripcie píše sa s koncovým -u. V analyzovanej knihe sme zaznamenali dvojaký zápis, s koncovým -u: šiu (s. 32), najšou (s. 49), strčiu, zlomiu (s. 50, s. 90), nekradou, uchmatou (s. 94). Druhý zápis 1-ového príčastia autorka zapísala s koncovým -v: prevrhov, zadrhov (s. 49), zanahav (s. 73). Podl'a pokynov dialektológov (Múcsková et al. 2012, 87) l-ové príčastie minulého času zapisujeme s koncovým -u. Slovesá majú zakončenie na -uvat' oproti spisovnému -ovat'. V skúmanom materiáli sme zaznamenali tieto príklady: bubnuvat', tancuvat' (s. 73), gajduvala, tancuvala, vikezuje (s. 75).

Pri verejnej čitatel'skej transkripcii sa píšu aj asimilačné a neutralizačné zmeny na rozhraní a na konci slov podl'a výslovnosti. Zápis podl’a uvedených pravidiel sme zaznamenali na s. 59 (zme), s. 68 (povec), s. 73 (f sobotu, nigda). Považujeme, že pri takomto zápise, vyznačovat' spodobovanie, vel'mi by pomýlilo čitatel'ov. Odporúčame dodržiavat' uvedené pravidlo pri vedeckých štúdiách a ukážkových textoch z dialektológie. 
V stredoslovenských nárečiach spoluhlásková skupina str- na začiatku slova sa zjednodušuje na sr-. V uvedenej zbierke zjednodušovanie sme nezaznamenali, spoluhlásková skupina bola zapísaná ako v spisovnej slovenčine: streda (s. 83). Rovnako aj spoluhlásková skupina -zdn- vnútri slova v stredoslovenských nárečiach sa zjednodušuje na -zn-. V našom výskume sme zjednodušovanie spoluhláskovej skupiny nezaznamenali, vyskytla sa spoluhlásková skupina -zdn- ako v spisovnej slovenčine (prázdne s.77).

To, čo upútalo našu pozornost', sú aj vlastné mená, ktoré sa vyskytli v analyzovaných textíkoch. Vo väčšine to boli mená, ktoré sa bežne vyskytujú v textoch uvedeného typu. Dievčenské mená v základnej, deminutívnej a hypokoristickej podobe: Anka (s. 12, s. 40), Anička (s. 30), Zuzana (s. 81), Mariša (s. 81), Mara (s. 92), Eva (s. 86), chlapčenské: Adam (s. 86), Abrahám (s. 86), Janko (s. 35), Janík (s. 61), Jano (s. 51), Janko Mrkvička (s. 48), Martin (s. 33), Pal'ko (s. 47), Duro (s. 96), Ďuro Bažal'a (s. 62), Peter (s. 59). Prekvapili nás tvary Elenka (s. 37) a Zdenko (s. 47), ktoré v minulosti neboli až tak bežné, že sa dostali do rozličných l'udových tvarov. Možno tu ovplyvnili aj informátori, ktorí svojim det'om dali spomenuté mená a tak sa dostali do textov. Nezvyčajne na nás zapôsobilo zemepisné vlastné meno Holíč, ktoré sa vyskytlo vo vojvodinskom kontexte: Holič Holý holí holiča z Holíča (s. 42). Možno tu išlo o modifikáciu vety z pera autorky. Určite na položenú otázku odpoved’ nám môže poskytnút' jedine autorka.

Knihu Enike benike krikel bé autorky Kataríny Mosnákovej-Bagl'ašovej oceňujeme pozitívne. Sú v nej zozbierané a zapísané vzácne texty, ktoré už zriedka poznajú mladšie generácie. Ked’že v súčasnosti je čoraz menej informátorov, ktorí poznajú verše, pesničky, rečňovanky, riekanky, vinše, ktoré sú zaznamenané v knihe, to iba zvyšuje na jej hodnote a význame. Vzácna zbierka nárečového materiálu by určite získala na vyššej kvalite, ked' by autorka alebo vydavatel' napísali predslov, v ktorom by odôvodnili zapisovanie nárečových textov. Určite by získala na kvalite aj vtedy, ked’ by pri zapisovaní nárečového materiálu autorka a vydavatel' konzultovali odborné publikácie z dialektológie a v neposlednom rade odborníkov z tejto oblasti. Jazyková redaktorka, ktorá sa podiel'ala pri vydaní knihy, má nepochybne dlhoročnú skúsenost' v uvedenej oblasti, ale zrejme neprihliadala na verejnú čitatel'skú transkripciu.

O každom texte v knihe sa dá osobitne hovorit'. Pri zápise každého textu nastali určité zvláštnosti, odklony pri zápise, ktoré navrhujeme transkripciou upravit’ a pozmenit' podobu.

Už v samotnej knihe nárečové texty sú zretel'ne vyčlenené inou farbou - červenou, od ostatného textu. Jednoducho bolo potrebné napísat', že piesne, básničky, rečňovanky, vyčítanky, vinše sú zapísané v stredoslovenskom nárečí a rozhodnút' sa, či použit' čitatel'skú nárečovú transkripciu alebo nie. V prípade, že by sa autorka a vydavatel' nerozhodli pre transkripciu, považujeme, že všetky texty by mali byt' zapísat' jednotne. Pretože ide o nárečové texty, pri zapisovaní by sa nemalo používat' tvrdé dlhé a krátke y, grafémy pre široké ä, ô.

Ďalej pri zapisovaní rečňovaniek, piesní, riekaniek, vinšov a iných veršov odporúčame postupovat' jednotne - používat' nárečovú podobu a nestriedat' so spisovnou.

Notovú čast' v knihe oceňujeme pozitívne. Je to vlastne pomôcka pre deti a rodičov, aby si mohli uvedené pesničky zaspievat' a podl'a možnosti aj zahrat' na hudob- 
nom nástroji. Len predtým by bolo potrebné zjednotit’ zápis piesní - textu pod notami a textu pred alebo po notovej časti.

Vyznačovat' spodobovanie spoluhlások v slove, na konci slova a na rozhraní slov $\mathrm{v}$ zbierke neodporúčame.

Rovnako tak treba brat' do ohl'adu aj skutočnost', že aj informátori pri podávaní nárečového materiálu mohli byt' ovplyvnení tým, že ich informácie sa zaznamenávajú a snažili sa použivat' spisovnú podobu jazyka. Preto vždy treba zdôraznit' podávatel’om informácií, aby používali nárečovú podobu jazyka.

Ked' by sa uvedené pokyny napísali v úvode pre rodičov, starých rodičov, učitel'ov a tých, ktorí budú knihu čítat' svojim det’om a vnúčatám, nenastali by žiadne pochybnosti u čitatel'ov.

Neanalyzovali sme všetky texty v knihe Enike benike krikel bé kvôli priestorovému obmedzeniu.

\section{Literatúra}

Dudok, Daniel. Č́́tanka nárečových textov Slovákov v Báčke, Banáte, Srieme a Slavónsku. Báčsky Petrovec: Slovenské vydavatel’ské centrum, 2010.

Dudok, Daniel. Nárečie Aradáča v Banáte na pozadí vzniku a vývinu obce. Báčsky Petrovec: Slovenské vydavatel'ské centrum, 2013.

Marićová, Anna. Slovenská nárečová lexika Starej Pazovy. Stará Pazova: Kanadem, 2010.

Múcsková, Gabriela, Muziková, Katarína, Wambach, Viera: Praktická dialektológia. (Vysokoškolská príručka na nárečovú interpretáciu. Bratislava: Filozofická fakulta Univerzity Komenského, Wien: Institut für Slawistik der Universität, 2012.

Mosnáková-Baglašová, Katarína: Detstvo našich predkov. Báčsky Petrovec: Slovenské vydavatel'ské centrum, 2016.

Mosnáková-Bagl'ašová, Katarína: Enike benike krikel bé. Báčsky Petrovec: Slovenské vydavatel'ské centrum, Nový Sad: Ústav pre kultúru vojvodinských Slovákov, 2017.

Slovník slovenských nárečí I A-K. (red. Ivor Ripka). Bratislava: Veda, vydavatel’stvo Slovenskej akadémie vied, 1994.

Slovník súčasného slovenského jazyka m-n. (red. Alexandra Jarošová). Bratislava: Veda, vydavatel'stvo Slovenskej akadémie vied, 2015. 
Ana Makišova

\section{ZAPISIVANJE DIJALEKATSKIH TEKSTOVA U IZDANJIMA KNJIGA U VOJVODINI}

\section{Rezime}

Predmet našeg istraživanja je bila mongrafija Katarine Mosnakove Bagljašove Enike benike krikel be stihovi pesama, pesmica, brojalica, rima. Analizirali smo način na koji su zapisani navedeni tekstovi, pošto je to u suštini dijalekatski materijal (tekstovi srednjeslovačkog dijalekatskog tipa iz Banata: Janošika, Aradca i Kovačice). Bagljašova prilikom zapisivanja dijalekatskog materijala nije postupala dosledno, to je neka kombinacija zapisa standardnim jezikom a delimično i dijalekatski zapis. Ni pravila dijalekatske transkripcije se ne primenjuju dosledno. Pozitivno ocenjujemo monografiju Enike, benike krikel be. Sakupljeni i zapisani su dragoceni tekstovi koje mlađe generacije i ne poznaju. Zbirka dijalektološkog materijala sigurno bi dobila na kvalitetu kada bi autor ili izdavač napisao predgovor u kom bi obrazložio zapisivanje dijalektoloških tekstova. Takođe autor ili izdavač imao je mogućnost da konsultuje stručne publikacije iz dijalektologije i lingviste o zapisivanju dijalekatskog materijala.

Ključne reči: Enike benike krikel be, dijalekatski zapis, standardni jezik, slovački jezik, transkripcija. 